\title{
The Empirical Study on the Improvement of College Students' Writing Ability in English Teaching
}

\author{
Cui Peng \\ Feixian Branch, Linyi University \\ Feixian, Shandong, China \\ cuipeng2008.ok@163.com
}

\begin{abstract}
In order to improve the college students' writing ability, this paper puts forward a new teaching model which combines the discourse analysis-based reading with writing. To test the effect of this new teaching model, the writer carried out an experiment in the Linyi University. The college students involved in this study are non-English majors and come from two natural classes, and one of them is the experimental group in which the new teaching model was adopted, the other is the controlled group in which the traditional teaching model was used. By analyzing the writing marks in the pretest and posttest after experiment, we found that students in each class made less mistakes than before at the level of vocabulary, grammar and discourse, but students in the EG made more achievements than those in the CG, especially at the level of discourse. The the results of posttest verified the effectiveness and feasibility of the new teaching model.
\end{abstract}

Keywords-discourse analysis, integration of reading and writing, writing ability

\section{INTRODUCTION}

As a kind of creative activity and a reflection of English comprehensive ability, English writing plays more and more important role in the English language learning. However, nowadays the students' writing ability are at the low level. As an English teacher in the college, the author finds that the mistakes they had in their writing works mainly concentrate on three levels, that is the level of vocabulary, grammar and discourse, and among which the mistakes at the discourse level are the most obvious one. The mistakes at the level of discourse can be mainly reflected in such aspects as the loose structure arrangement, the uncertainty of theme, the lack of coherence and cohesion among sentences and paragraphs, etc. The main reason is that teachers attached more importance to the points at the sentence level and neglected the discourse analysis in the college English teaching.

However, the results and achievements are far from satisfactory in the current higher vocational college English teaching. In the first place, the teaching time is very limited and teaching task is very heavy. In the second place, most teachers have been putting great emphasis on the reading teaching in the whole teaching period, which leads to little time left for writing. Therefore, how to improve the students' writing ability becomes a major concern for many English teachers in the college.
Under such circumstance, it is critical and necessary to explore a teaching reform in the college English teaching. Based on the theory relevant to the reading and writing and the previous achievements made by others observers, the author thinks it's wise to attach much importance to the discourse analysis in the reading class and then combine the writing exercise correspondingly and so puts forward the new teaching model which combines the discourse analysis-based reading with writing in order to improve students' writing ability.

\section{LITERATURE REVIEW}

\section{A. Discourse Analysis}

As to the discourse analysis, many scholars once gave their own definition or description. For example, D.Numan(1993) defined discourse analysis as the functional analysis of discourse, different from the text analysis that emphasizes the characteristics of language system. In Zhou Guangming \& Guan Changqing's view (2001), discourse analysis analyzes the textual pattern first, and then the relationship between different sentences and passages in order to make students master the main idea of the whole text and have the ability to have better understanding and achieve the teaching aim in the end.

From the functional point of view, discourse analysis refers to the relationship between language and the context in which it exists. Specifically speaking, Discourse analysis is a kind of comprehension and analysis of the text from the perspective of unity, and it includes the micro-structure analysis and macro-structure analysis (Huang Guowen, 2001:6).Macro-structure Analysis can not be completely decoded if the analysis of discourse just stays at word or sentence level. As the communicative unit, the discourse is arranged by a certain textual pattern.

Micro-structure Analysis explores how a series of sentences make up a coherent discourse via lexical cohesion, grammatical devices and logical connection. So from the micro-structure perspective, the main study of discourse includes the analysis of cohesion, coherence and context. For example, cohesion is the tangible network of discourse and the main content in the discourse analysis.

\section{B. The Integration of Reading and Writing Studies at Home and Abroad}

\section{1) Studies Abroad}

English reading and writing research areas had a close contact with each other in the early 1980s. Since then, 
foreign theorists in these two areas have been paying more and more attention to the integration of reading and writing.

Carson \& Careel(1990)not only made an empirical study on the relationship between the second language reading and writing, they also traced out the migration of reading and writing skills between languages. The results showed that the higher level they had at the learning of second language, the more relevance between second language reading and writing occurred and would more possibly have the migration of reading and writing skills between languages. They also pointed out that the second language reading and writing have many aspects in common, such as language form and function. Just as writing is not simply to improve writing skills, reading activities are not simply used to improve reading skills.

Stotsky (1998) believed that reading experience has a close touch with writing ability, good writers should firstly be good readers and good readers can write more mature and authentic article.", He believed that reading is a efficient way to have great influence on the writing.

Grabe (2002) gave some examples to illustrate the point that intensive reading can indirectly lead to better writing and reading and writing perform the same function of communication.

Clouse (2004) proposed that language learners would be more sensitive to the demands for the needs of readers if they read more discourses. Hyland (2005) believed that reading and writing are the most basic source for the world of experience we understand and the link built between us and the others

\section{2) Studies at Home}

Studies on the integration of reading and writing have been observed by Chinese scholars since 1990s.

Xie Weina (1994) illustrated in particular the relationship between reading and writing: the process of writing is actually a simulation of the process of reading, and reading is also the behavior that stimulates writing. Because readers must guess the role the writer played in the discourse and make sense of the writer's intention during the reading period. In other words, both process of writing and reading interact with each other.

Chen Liping(2000)thought it proper to combine the teaching of reading with writing by means of modeling teaching.and in the experiment, she tested the effectiveness of the integration of reading and writing

Sheng Yiying (2005) analyzed the relationship between reading and writing and arrived at the conclusion that effective reading can help language learners improve their writing ability to the larger extent.

Cao Zhongqin(2008) tried to explore whether the integration of reading and writing had great influence on students' writing skills by using the quantitative and qualitative analysis method. They took non-English majors belonging to the undergraduate institutions in one province as the experimental subjects, emphasizing the process of reading teaching and the revision of writing. In short, they made out that the new teaching model ---the integration of reading and writing could further improve students' writing ability.

Yuan Jun(2010)believed that it's practical way to improve students' writing ability and the college English teaching if the integration of discourse analysis-based reading and writing can be used.
As is mentioned above, some researches from abroad based the teaching model of integrating reading and writing on their native language. Others made such in the environment of taking English as the second language. While in China more and more researchers paid more attention to the theoretical study on the integration of reading and writing. But few of them mentioned the integration of discourse analysis-based reading and writing used in the college. Hence this thesis proposes this new model and will make an empirical study on the students to test whether it can improve the students' writing ability in the college.

\section{RESEARCH METHODOLOGY}

\section{A. Hypothesis}

Before making this experiment, three questions will be put forward: 1)What influences does the new teaching model have on the improvement of the college students' writing ability? 2)Does this new teaching model have more effect than the traditional teaching model? If so, in which aspects can be presented? 3)What enlightenment can this new teaching model bring about in improving the English teaching model in college?

From these questions, a hypothesis can be formed: This new teaching model that combines the discourse analysisbased reading with writing in the English teaching can improve the students' writing ability in the college effectively.

\section{B. Subjects}

The First-year students taken as subjects in this teaching experiment came from Linyi University Feixian Campus in Shandong Province and these students majoring in advertising were chosen from two natural classes (Class Three \& Class Four). All students came from the senior middle school and they had been studying English for almost six years. Their ages ranged from 19 to 21 and they had the same learning experience and the same English level. Most importantly, they had never been trained by the way of integrating reading with writing before entering higher college. Class Three made up of 40 students can be chosen as the experimental group (EG), Class Four as the control group (CG) was also made up of 40 students. These students were assigned into each class in average according to their scores in the college entrance examination and both classes were instructed by the same English teacher-the researcher himself.

\section{Instruments}

The instruments in this experimental study were made up of pre-test, post-test, teaching material.The pre-test was adopted from the quality test following the entrance examination for college students in September, 2014; the post-test was from the final exam for college students in January, 2015. Both tests were given from the higher administration-Linyi University and the difficulty of two tests were at the same level, which can bring about the validity and reliability. The teaching material used in both CG and EG was the textbook named the New Times College English (Book One). 


\section{Procedure}

\section{1) Pre-test}

All subjects involved in this study were given an English quality test as a pre-test on September 12, 2014, from which the researcher collected the reading and the writing scores respectively in order to know whether their reading and writing ability were at the same level. The test lasted for three hours and there was enough time for students to do each part on the test paper. The marks in the reading and writing parts were evaluated strictly according to the requirements of this qualitative test given by the higher administration-Linyi University in Shandong Province.

For the reading part on the test paper, two experienced teachers gave the marks respectively and then the average score was given to each subject. For the writing part, another three experienced teachers who never taught subjects in CG and EG were invited. During the whole process, they first used the way of total scoring, and then the average score was calculated as the final marks for each subject, which can ensure the objectivity and justice of this test. Finally all scores were put into the computer and analyze the data by the spss 13.0. Meanwhile some aspects of discourse in each student's writing (such as topic sentence, discourse structure, lexical cohesion, etc.) can be listed.

\section{2) Teaching experiment}

After the pre-test in the first week of this new term, all subjects in the CG and EG were trained with two different teaching models in the following 14 weeks. The new teaching model that combines the discourse analysis-based reading with writing was adopted in the EG, that is students were taught the reading text in each unit with the discourse analysis-based reading method first, and then they were given a assignment to write, that is write a composition which had the similar theme or discourse structure learned in the reading class. The students finished the writing in two ways. One way was to require students to write a composition which was similar to the discourse structure they had learned at the given time in the class. The other was to assign writing after class. The traditional teaching method which mainly focused on the vocabulary and grammar in the reading teaching was used in the $C G$, and the arrangements of writing such as content, the times, the way of evaluation are the same as those in the EG. All these subjects had four classes per week and they were taught by the same English teacher, using the same textbook. In this study, each student in CG and EG wrote 14 compositions respectively.

\section{3) Post-test}

After trained by the different teaching model, all students in $\mathrm{CG}$ and EG took part in the final exam as the post-test on January 12, 2015 (week 16). This test was also arranged by the higher administration-Linyi University. The students' seat were distributed by the computer and the test which lasted three hours can make students have enough time to accomplish each part on the test paper. The experienced teachers who were involved in the pre-test gave the reading or writing parts the marks correspondingly and strictly according to the requirements of standard for this test. The average score for each part can be used as the final score and put into computer to analyze by the software SPSS 13.0. At the same time, the aspects in each student's writing paper from the microstructure and macro-structure perspective can also be listed.

4) Data collection and analysis

The Data in this experiment mainly consist of two parts: the data of pre-test and post-test. Four parts of data were collected on each test: the first was the marks of reading test(30 points), the others were the marks of writing test(15 points), the mistakes and the application of some aspects such as topic sentence, discourse structure, lexical cohesion ,etc. All data were put into the computer and analyzed with the help of software SPSS 13.0.

\section{RESUlTS AND DisCUSSION}

\section{A. Results of Pretest}

In this period, all the data such as the scores, the mistakes and skills at the discourse level in the writing part and the scores in the reading part were collected and put into computer and analyzed by the statistical software spss13.0.The results are as follows:

TABLE I. THE RESULTS OF INDEPENDENT SAMPLES TEST IN THE WRITING PART (GROUP STATISTICS)

\begin{tabular}{|l|l|l|l|l|}
\hline Group & $\mathrm{N}$ & Mean & Std.Deviation & $\begin{array}{l}\text { Std.Error } \\
\text { Mean }\end{array}$ \\
\hline Pretest EG & 40 & 8.225 & 1.5104 & .2389 \\
CG & 40 & 8.400 & 1.5326 & .2423 \\
\hline
\end{tabular}

From the table 4.1, we can find that the mean of English writing in the EG is 8.2250 points and that of writing in the $\mathrm{CG}$ is 8.4000 points. By contrast, the average score of EG is only lower than $\mathrm{CG}$ by 0.175 points, which is also provided in the column of mean difference. Besides, we can also find that $\mathrm{p}=0.608>0.05$ and the $95 \%$ Confidence Interval of the Difference is between -.8523 and 0.5023 which includes zero. All facts suggest that there was no significant difference between the average score of EG and CG, that is to say, the 80 students' writing ability in both groups were at the same level before the experiment.

TABLE II. THE RESUlTS OF MISTAKES STUDENTS GOT IN THE WRITING

\begin{tabular}{|c|c|c|c|}
\hline Group & $\begin{array}{c}\text { vocabulary } \\
\text { mistakes }\end{array}$ & $\begin{array}{c}\text { grammar } \\
\text { mistakes }\end{array}$ & $\begin{array}{c}\text { discourse } \\
\text { mistakes }\end{array}$ \\
\hline EG & 142 & 178 & 276 \\
\hline CG & 140 & 162 & 260 \\
\hline
\end{tabular}

From this table, we can see that the number of mistakes students made in the EG was almost as equivalent as those in the CG in terms of vocabulary, grammar and discourse.

TABLE III. THE RESULTS OF SKILLS AT DISCOURSE LEVEL IN THE WRITING

\begin{tabular}{|c|c|c|c|c|c|}
\hline Group & $\begin{array}{c}\text { paragraph } \\
\text { assignment }\end{array}$ & $\begin{array}{c}\text { topic } \\
\text { sentence }\end{array}$ & $\begin{array}{c}\text { logical } \\
\text { cohesion }\end{array}$ & $\begin{array}{c}\text { Lexical } \\
\text { cohesion }\end{array}$ & $\begin{array}{c}\text { grammatical } \\
\text { cohesion }\end{array}$ \\
\hline EG & 1.1 & 0.7 & 1.2 & 1.7 & 14 \\
\hline CG & 1.2 & 0.7 & 1.3 & 1.8 & 15 \\
\hline
\end{tabular}

In this table, all data stand for the average number in each section. For example, the average number of the paragraph arrangement in EG is 1.1, while is 1.2 in the CG. From what showed in this table, we can find that students 
in both groups had almost the same skills of discourse analysis at the macro-level and micro-level.

From what's discussed above, we can draw the conclusion that students in the EG had the same reading and writing ability as those in the CG before experiment. The main reason for that lies in the fact that they were chosen to enter this college and arranged into these two classes both by their marks in the entrance examination, and their English ability were at the same level in general though they graduated from different senior middle schools. The results of pretest would ensure the possibility of conducting this experiment and test the effect of two different teaching models further in the following 14 weeks.

\section{B. Results of Posttest}

With the help of computer, the results of posttest from three aspects will be showed, that is the data for the independent samples test, the mistake numbers in word, grammar and discourse, the statistics at the discourse level.

TABLE IV. THE RESULTS OF INDEPENDENT SAMPLES TEST IN THE WRITING PART (GROUP STATISTICS)

\begin{tabular}{|c|c|c|c|c|}
\hline Group & $\mathrm{N}$ & Mean & Std.Deviation & Std.Error Mean \\
\hline Pretest EG & 40 & 11.250 & 1.1712 & .1852 \\
CG & 40 & 9.125 & 1.1808 & .1867 \\
\hline
\end{tabular}

From the table 4.4 , we can find that the mean of English writing in the EG is 11.250 points and that of writing in the CG is 9.1250 points. The average score of EG is higher than that of CG by 2.125 points. What's more, we can also find in the column of Independent Samples Test that $\mathrm{p}=0.000<0.05$ and the $95 \%$ Confidence Interval of the Difference is between 1.6015 and 2.6485 which doesn't include zero. All these facts suggest that there was great significant difference between the average score of the EG and CG, that is to say, the students in the EG made greater progress than those in the $\mathrm{CG}$ after being taught by different teaching models for 14 weeks.

TABLE V. THE RESULTS OF MISTAKES STUDENTS GOT IN THE WRITING

\begin{tabular}{|c|c|c|c|}
\hline Group & $\begin{array}{c}\text { vocabulary } \\
\text { mistakes }\end{array}$ & $\begin{array}{c}\text { grammar } \\
\text { mistakes }\end{array}$ & $\begin{array}{c}\text { discourse } \\
\text { mistakes }\end{array}$ \\
\hline EG & 102 & 132 & 105 \\
\hline CG & 125 & 139 & 200 \\
\hline
\end{tabular}

In this table, we can find that students in the EG made greater progress in the following 14 weeks. The students in EG made less mistakes than those in the CG, that is less mistakes by 23 in vocabulary, less mistakes by 7 in grammar, less mistakes by 95 in discourse. This also shows that the students' writing ability especially at the discourse level has greatly improved.

TABLE VI. THE RESULTS OF SKILLS AT DISCOURSE LEVEL IN THE WRITING

\begin{tabular}{|c|c|c|c|c|c|}
\hline Group & $\begin{array}{c}\text { paragraph } \\
\text { assignment }\end{array}$ & $\begin{array}{c}\text { topic } \\
\text { sentence }\end{array}$ & $\begin{array}{c}\text { logical } \\
\text { cohesion }\end{array}$ & $\begin{array}{c}\text { lexical } \\
\text { cohesion }\end{array}$ & $\begin{array}{c}\text { grammatical } \\
\text { cohesion }\end{array}$ \\
\hline EG & 3.0 & 2.7 & 4.7 & 4.0 & 30 \\
\hline CG & 2.0 & 1.6 & 2.1 & 2.7 & 23 \\
\hline
\end{tabular}

In this table, the average number students got in the EG was higher than that in the CG. These facts show that students in EG had higher ability in the application of discourse skills after being taught by the new teaching model, especially in such aspects as paragraph assignment, topic sentence, and cohesion.

According to the analysis, we can see that students in both groups made progress in the 14 weeks for experiment. But students in the EG made greater improvement in dealing with the discourse at the macro and micro-level. By contrast, the average number of paragraph assignment students in the EG got went up by 173 percent (3.0/1.1$1.1 / 1.1$ ), the other parts in the EG went up by 286 percent, 292 percent, 135 percent and 113 percent respectively. While students in the CG made less progress compared with those in the EG, the average number of each part went up by 67 percent, 129 percent, 62 percent, 50 percent, and 53 percent respectively. It shows that students in the EG paid more attention to the discourse aspects at the macro-level and micro-level, and made greater progress than students of CG. The main reason for that result is that students learned more about the discourse analysis in the reading and put what they had learned into their writing.

From what's mentioned above, we can see that students in both groups made progress in writing, but the students in the EG made more achievements than those in the $\mathrm{CG}$, especially at the discourse level.

\section{Comparison of the Results of the Pretest and Posttest and Discussion}

TABLE VII. THE NUMBER OF MISTAKES IN BOTH TESTS IN THEEG

\begin{tabular}{|c|c|c|c|}
\hline & $\begin{array}{c}\text { Vocabulary } \\
\text { mistakes }\end{array}$ & $\begin{array}{c}\text { Grammar } \\
\text { mistakes }\end{array}$ & $\begin{array}{c}\text { Discourse } \\
\text { mistakes }\end{array}$ \\
\hline pretest & 142 & 178 & 276 \\
\hline posttest & 102 & 132 & 105 \\
\hline
\end{tabular}

TABLE VIII. THE NUMBER OF MISTAKES IN BOTH TES TS IN THE CG

\begin{tabular}{|c|c|c|c|}
\hline & $\begin{array}{c}\text { Vocabulary } \\
\text { mistakes }\end{array}$ & $\begin{array}{c}\text { Grammar } \\
\text { mistakes }\end{array}$ & $\begin{array}{c}\text { Discourse } \\
\text { mistakes }\end{array}$ \\
\hline pretest & 140 & 162 & 260 \\
\hline posttest & 125 & 139 & 200 \\
\hline
\end{tabular}

From the table listed in the EG, students made less mistakes in posttest than in the pretest, that is less mistakes by 40 in vocabulary, by 46 in grammar, and by 171 in discourse. While in the $\mathrm{CG}$, students also made less mistakes in the posttest than in the pretest, that is less vocabulary mistakes by 15 , less grammar mistakes by 23 , and less discourse mistakes by 60 . It indicates that students in the EG made less mistakes than in the CG after experiment, more obviously in the discourse mistakes. The main reason lies in the fact that the new teaching model used in the EG is more efficient than the traditional teaching model. 
TABLE IX. THE APPLICATION OF DISCOURSE SKILLS IN THE EG

\begin{tabular}{|c|c|c|c|c|c|}
\hline & $\begin{array}{c}\text { paragraph } \\
\text { assignment }\end{array}$ & $\begin{array}{c}\text { topic } \\
\text { sentence }\end{array}$ & $\begin{array}{c}\text { logical } \\
\text { cohesion }\end{array}$ & $\begin{array}{c}\text { lexical } \\
\text { cohesion }\end{array}$ & $\begin{array}{c}\text { grammatical } \\
\text { cohesion }\end{array}$ \\
\hline pretest & 1.1 & 0.7 & 1.2 & 1.7 & 14 \\
\hline posttest & 3.0 & 2.7 & 4.7 & 4.0 & 30 \\
\hline
\end{tabular}

TABLE X. THE APPLICATION OF DISCOURSE SKILLS IN THE CG

\begin{tabular}{|c|c|c|c|c|c|}
\hline & $\begin{array}{c}\text { paragraph } \\
\text { assignment }\end{array}$ & $\begin{array}{c}\text { topic } \\
\text { sentence }\end{array}$ & $\begin{array}{c}\text { logical } \\
\text { cohesion }\end{array}$ & $\begin{array}{c}\text { lexical } \\
\text { cohesion }\end{array}$ & $\begin{array}{c}\text { grammatical } \\
\text { cohesion }\end{array}$ \\
\hline pretest & 1.2 & 0.7 & 1.3 & 1.8 & 15 \\
\hline posttest & 2.0 & 1.6 & 2.1 & 2.7 & 23 \\
\hline
\end{tabular}

In this table, we can see that students in both groups made progress in the 14 weeks for experiment. But students in the EG made greater improvement in dealing with the discourse at the macro and micro-level. By contrast, the average number of paragraph assignment students in the EG got went up by 173 percent (3.0/1.11.1/1.1), the other parts in the EG went up by 286 percent, 292 percent, 135 percent and 113 percent respectively. While students in the CG made less progress compared with those in the EG, the average number of each part went up by 67 percent, 129 percent, 62 percent, 50 percent, and 53 percent respectively. It shows that students in the EG paid more attention to the discourse aspects at the macro-level and micro-level, and made greater progress than students of CG. The main reason for that result is that students learned more about the discourse analysis in the reading and put what they had learned into their writing.

From what's mentioned above, we can see that students in both groups made progress in writing, but the students in the EG made more achievements than those in the CG, especially at the discourse level.

\section{CONCLUSION}

This study shows that the new teaching model which combines the discourse analysis-based reading with writing is effective in improving the students' writing ability in the college. The results of the Paired Sample T Test on the writing scores in the EG show that $\operatorname{sig}(2-$ tailed $)=.000<0.05,0$ is not included between -3.39 and 2.66 , which indicates the obvious difference between the pretest and posttest. Besides, $\mathrm{M}=11.25>9.13$ indicates that the students in the EC have made greater progress in writing. The results in the independent sample T test show that $\operatorname{sig}(2$-tailed $)=.000<0.05,0$ is not included between 1.6015 and 2.6485, which demonstrates a great significant difference in the English writing especially on the discourse level between the EG and the CG..Besides, $M=11.250>9.125$ shows that students in the EG made more achievements than those in the CG after adopting different teaching model.What' $\mathrm{s}$ more, this new teaching model can bring great effect on the improvement of students' reading ability and can arouse students' great interest in the English writing.During the empirical study, students can cooperate with their partners actively and put forward What they think is beneficial for them. They use their minds to put what's discussed into practice and can accomplish the task by using the adequate material.Although the results of what's mentioned above is indeed effective, this study has also its limitations such as the researcher's time, ability and the insufficiency of data, which can not make this study accurate and in-depth neither. Therefore, more practice should be made to test its validity and feasibility and further studies of this new teaching model which combines discourse analysis-based reading with writing in English classroom teaching are to be expected.

\section{REFERENCES}

[1] Carson,J.\&Careel.P.L.Reading-writing Relationships in First and Second Language.TESOL Quarterly, 1990.

[2] Clouse, B.F. The student writer: editor and critic-6th ed.New York:McGraw-Hill.2004.

[3] Hyland.K..Second language writing[M]Cambridge:Cambridge University Press.2003.

[4] Grabe,W.Reading-Writing Relations: Theoretical Perspective and Instructional Practices, Perspectives on L2 Reading-Writing Connections. The Ohio University,pp. 2002.

[5] Stotsky,S.Research on the Reading/Writing Relationships:A Synthesis and Suggested Directions.Language Arts, 1998.

[6] Cao Zhongqin.The Input and Output Theory and the Improvement of English Writing Level, The Journal of Hebei University of Economics and Business ,2008.

[7] Chen Liping.The Model Teaching in the Writing Teaching from the Perspective of Reading and Writing, Foreign Language and Their Teaching,2001.

[8] Xie Weina. The Integration of Reading and Writing, Foreign Language Education, 1994.

[9] Yuan Jun.The Discussion about the Integration of Reading and Writing in the the College English Teaching, Social Science Edition Journal of MUDanjiang Normal University,2010.

[10] Zhou Guangming\&Guan Changqin.Discourse Analysis is the Effective Approach in the English Reading Reaching, the Journal of Hubei Normal College, 2001. 